\title{
INVESTIGATION OF SOLVENT EFFECTS ON ELECTRONIC ABSORPTION SPECTRA OF SOME SUBSTITUTED 1,2,4-TRIAZOLINE-3-THIONES
}

\author{
Mirjana Jankulovska ${ }^{1}$, Lidija Šoptrajanova ${ }^{1}$, Ilinka Spirevska ${ }^{1}$, \\ Katica Čolančevska-Ragenovi $\kappa^{2}$, Saško Ristovski ${ }^{1}$ \\ ${ }^{1}$ Institute of Chemistry, Faculty of Natural Sciences and Mathematics, \\ SS Cyril and Methodius University of Skopje, \\ Arhimedova 5, P. O. Box 162, MK-1001 Skopje, Republic of Macedonia \\ ${ }^{2}$ SS Cyril and Methodius University of Skopje, Faculty of Technology and Metallurgy, \\ P.O. Box 580, MK-1001 Skopje, Republic of Macedonia \\ jankulovska_m@yahoo.com
}

\begin{abstract}
The influence of the polarity of the solvent and hydrogen bonding on the electronic absorption spectra of some previously synthesized substituted 1,2,4-triazoline-3-thiones was studied. The electronic absorption spectra of investigated compounds were recorded in the region from $190 \mathrm{~nm}$ to $360 \mathrm{~nm}$ in eight protic (water, ethylene glycol, methanol, ethanol, propan-1-ol, propan-2-ol, butan-1-ol and tert-butanol) and five aprotic (acetonitrile, chloroform, dimethylsulfoxide, dimethylformamide and dioxane) solvents. Their absorption maxima appeared in the region between $250 \mathrm{~nm}$ and $260 \mathrm{~nm}$ as a result of the electron transitions in the 1,2,4-triazoline-3-thione ring. Using the method of linear solvation energy relationships (LSER), the effects of solvent polarity and hydrogen bonding on the electronic absorption spectra were interpreted. The results have shown that the influence of the aprotic solvents is more significant compared to that of the protic solvents.
\end{abstract}

Key words: 4-butyl-5-octyl-2,4-dihydro-3H-1,2,4-triazoline-3-thione; 4-allyl-5-octyl-2,4-dihydro-3H-1,2,4-triazoline-3-thione; 4-phenyl-5-octyl-2,4-dihydro-3H-1,2,4-triazoline-3-thione; electronic absorption spectra; solvent effects; linear solvation energy relationship (LSER)

\section{ИСПИТУВАЊЕ НА ВЛИЈАНИЕТО НА РАСТВОРУВАЧОТ ВРЗ АПСОРПЦИОНИТЕ СПЕКТРИ НА НЕКОИ СУПСТИТУИРАНИ 1,2,4-ТРИАЗОЛИН-3-ТИОНИ}

\footnotetext{
Испитано е влијанието на поларноста на растворувачот и на создавањето водородни врски врз електронските апсорпциони спектри на некои претходно синтетизирани супституирани 1,2,4-триазолин-3-тиони. Снимени се електронски апсорпциони спектри во осум протични (вода, гликол, метанол, етанол, пропан-1-ол, пропан-2-ол, бутан-1-ол и $t$-бутанол) и пет апротични (ацетонитрил, хлороформ, диметилсулфоксид, диоксан и диметилформамид) растворувачи, во спектрално подрачје од $190 \mathrm{~nm}$ до $360 \mathrm{~nm}$. Апсорпциони максимуми на испитуваните соединенија се појавуваат во подрачјето помеѓу $250 \mathrm{~nm}$ и $260 \mathrm{~nm}$, како резултат на електронски премини во 1,2,4-триазолин-3-тионскиот прстен. За да се објасни создавањето водородни врски и влијанието на поларноста на растворувачот врз апсорпционите спектри, користени се методите базирани на линеарна корелација на солватационите ефекти (LSER). Добиените резултати покажуваат дека влијанието на апротичните растворувачи во однос на протичните е поизразено.
}

Клучни зборови: 4-бутил-5-октил-2,4-дихидро-3Н-1,2,4-триазолин-3-тион; 4-алил-5-октил-2,4-дихидро-3Н1,2,4-триазолин-3-тион; 4-фенил-5-октил-2,4-дихидро-3Н-1,2,4-триазолин-3-тион; електронски апсорпциони спектри; апротични растворувачи; влијание на растворувач; линеарна корелација на солватациони ефекти (LSER) 


\section{INTRODUCTION}

It is known that 1,2,4-triazole and its derivatives possess biological activity [1-7] and so they could be used in medicine as: anticancerous, antiinflammatory, antiviral, antiasthmatic, analgesic and antibacterial drugs [1-5]. Some authors $[8,9]$ presume that the antiviral and the antibacterial activities of the investigated compounds are as a result of the $-\mathrm{NH}-\mathrm{C}(\mathrm{S})-\mathrm{NH}-$ group in their molecule and that the positive/negative changes in the activity depend on the type of their substituents in position 4 of the ring.

The derivatives of the 1,2,4-triazoline also possess fungicidal, insecticidal and herbicidal properties $[10,11]$ and could be used in the chemical industry and agriculture. Because of the wide use of these compounds there is a big interest to synthesize and investigate their electronic behaviour.

The structural formulas of the compounds that were subject of our investigation are as below.

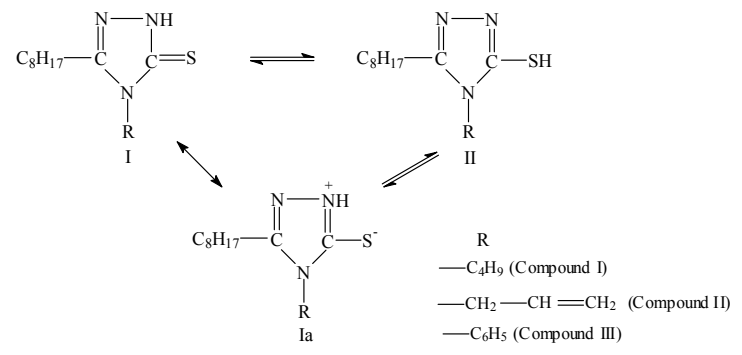

Fig. 1. The equilibrium between thione (I) and thiol (II) forms of 4-substituted-5-octyl-2,4-dihydro-3H-1,2,4-triazoline-3thiones and canonical structure (Ia)

The investigated compounds: 4-butyl-5-octyl2,4-dihydro-3H-1,2,4-triazo-line-3-thione (compound I), 4-allyl-5-octyl-2,4-dihydro-3H-1,2,4triazo-line-3-thione (compound II), 4-phenyl-5octyl-2,4-dihydro-3H-1,2,4-triazoline-3-thione (compound III) were synthesized by Ragenoviḱ et al. [12] and their structure was confirmed using spectroscopic methods as: ultraviolet (UV), Infra red (IR), and nuclear magnetic resonance $\left({ }^{1} \mathrm{H}\right.$ NMR and ${ }^{13} \mathbf{C}$ NMR) methods.

These compounds may exist in thione-thiol tautomeric forms (see Fig. 1). The IR and NMR data of all compounds suggest that the thione structures predominate in the solid state [12].
The solvent could influence the kinetics of the reactions in which the investigated compounds participate, and the electron transfer processes. Because of that, choosing the appropriate solvent is important for studying the reactions that take place in defined media.

Hence, the aim of the work was to delineate the different interactions of polar protic and aprotic solvents with previously synthesized 1,2,4triazoline-3-thiones.

The effects of the solvent polarity and hydrogen bonding on the absorption spectra of the investigated compounds were interpreted by means of linear solvation energy relationship (LSER), using the Kamlet and Taft equation (1) [13-15]. They improved solvatochromic coefficients $s, a$ and $b$ using the general solvatochromic equation (1) of the form:

$$
\tilde{V}_{\max }=\tilde{v}_{\mathrm{o}}+s \pi^{*}+a \alpha+b \beta
$$

where $\tilde{\nu}_{\max }=1 / \lambda_{\max }$ is the absorption frequency calculated using $\lambda_{\max }, \alpha, \beta$ and $\pi^{*}$ are solvatochromic parameters, and $s, a$ and $b$ are solvatochromic coefficients.

$\pi^{*}$ is the index of the solvent polarity, which is a measure of the ability of a solvent to stabilize a charge or a dipole by its own dielectric effects. The $\pi^{*}$ scale was selected to range from 0.00 for cyclohexanone to 1.00 for dimethyl sulfoxide. The $\alpha$ coefficient represents the solvent hydrogen bond donor (HBD) acidity, in other words it describes the ability of a solvent to donate a proton in a solvent-to-solute hydrogen bond. The $\alpha$ scale extends from 0.00 for non-HBD solvents to about 1.00 for methanol. The $\beta$ coefficient is a measure of the solvent hydrogen bond acceptor (HBA) basicity, and describes the ability of a solvent to accept a proton in a solute-to-solvent hydrogen bond. The $\beta$ scale was selected to extend from 0.00 for nonHBD solvents to about 1.00 for hexamethylphosphoric acid triamide. The $\tilde{V}_{\mathrm{o}}$ is the regression value of the solute property in cyclohexane as a reference solvent. The regression coefficients $s, a$ and $b$ in Eq. (1) measure the relative susceptibilities of the solvent-dependent solute property (absorption frequencies) to the indicated solvent parameters.

The total solvatochromic Eq. (1) gives information about the specific interaction solvent-solute and possibility to explain, quantificate, rationalize and correlate the solvent effects with the solvato- 
chromic parameters $\alpha, \beta$ and $\pi^{*}$ for the used solvents. The values of the solvatochromic parameters $\alpha, \beta$ and $\pi^{*}$, for protic and aprotic solvents [13-15], are shown in Table 1.

Table 1

The values of solvatochromic parameters $\alpha, \beta$ and $\pi^{*}$ for polar (protic and aprotic) solvents

\begin{tabular}{|c|c|c|c|}
\hline \multirow[b]{2}{*}{ Solvent } & $\pi^{*}$ & $\alpha$ & $\beta$ \\
\hline & \multicolumn{3}{|c|}{ Protic solvents } \\
\hline Water & 1.09 & 1.17 & 0.18 \\
\hline Ethylene glycol & 0.85 & 0.92 & 0.52 \\
\hline Methanol & 0.60 & 0.93 & 0.60 \\
\hline Ethanol & 0.54 & 0.83 & 0.77 \\
\hline Propan-1-ol & 0.52 & 0.78 & 0.00 \\
\hline Propan-2-ol & 0.46 & 0.78 & 0.95 \\
\hline Butan-1-ol & 0.47 & 0.79 & 0.88 \\
\hline \multirow[t]{2}{*}{ tert-Butanol } & 0.41 & 0.62 & 1.01 \\
\hline & \multicolumn{3}{|c|}{ Aprotic solvents } \\
\hline Chloroform & 0.58 & 0.44 & 0.00 \\
\hline Acetonitrile & 0.75 & 0.19 & 0.31 \\
\hline Dioxane & 0.55 & 0.00 & 0.37 \\
\hline Dimethylsulfoxide & 1.00 & 0.00 & 0.76 \\
\hline$N . N$-Dimethylformamide & 0.88 & 0.00 & 0.63 \\
\hline
\end{tabular}

\section{EXPERIMENTAL}

The stock solutions of the investigated compounds: 4-butyl-5-octyl-2,4-dihydro-3H-1,2,4-triazoline-3-thione (compound I), 4-allyl-5-octyl-2,4dihydro-3H-1,2,4-triazoline-3-thione (compound II), 4-phenyl-5-octyl-2,4-dihydro-3H-1,2,4-triazoline-3-thione (compound III) were prepared by dissolving adequate mass in $96 \%$ ethanol, at room temperature. The concentration of the investigated compounds in the stock solutions was about $1.0 \cdot 10^{-3} \mathrm{~mol} / \mathrm{dm}^{3}$. The ethanol was appropriate solvent for the investigated compounds because there were no bands in its spectrum in the region between $204 \mathrm{~nm}$ and $360 \mathrm{~nm}$. The concentration of the investigated compounds in the test solutions was $2.0 \cdot 10^{-5} \mathrm{~mol} / \mathrm{dm}^{3}$. The UV spectra of the investigated compounds were recorded in the following solvents: water, ethylene glycol, methanol, ethanol, propan-1-ol, propan-2-ol, butan-1-ol and tert-butanol, acetonitrile, chloroform, dioxane, dimethylsulfoxide and $N, N$-dimethylformamide.
All solvents were of the UV spectral grade. Parallely, the blanks were prepared. The investigated compounds were of the analytical grade p.a. It was confirmed by the quantitative elemental analysis and the recorded IR and NMR spectra [12]. The UV spectra were recorded on a Varian Cary 50 spectrophotometer (the maximum scan rate is $24000 \mathrm{~nm} / \mathrm{min}$ and resolution is $1.5 \mathrm{~nm}$ ) in the region between $190 \mathrm{~nm}$ and $360 \mathrm{~nm}$. The UV spectra were recorded immediately after the preparation of solutions, at room temperature. The quartz cell with the length of $1 \mathrm{~cm}$ was used. The results were obtained using the computer programs: Microsoft Excel, Grams Version 4.10 and Origin 5.0.

\section{RESULTS AND DISCUSSION}

The electronic absorption spectra of 4-butyl5-octyl-2,4-dihydro-3H-1,2,4-triazoline-3-thione (compound I), 4-allyl-5-octyl-2,4-dihydro-3H-1,2,4-triazo-line-3-thione (compound II), 4-phenyl-5-octyl2,4-dihydro-3H-1,2,4-triazoline-3-thione (compound III) were recorded. In order to explain the effects of the solvent polarity and hydrogen bonding on these spectra, thirteen different solvents were used: eight protic (water, ethylene glycol, methanol, ethanol, propan-1-ol, propan-2-ol, butan-1-ol and tert-butanol) and five aprotic (chloroform, acetonitrile, dioxane, dimethylsulfoxide and $\mathrm{N}, \mathrm{N}$-dimethylformamide) solvents. The absorption maxima in the region from 250 to $260 \mathrm{~nm}$ are characteristic for the heterocyclic class of compounds such as for the investigated ones [16]. It was confirmed with our previous examinations of electronic spectra of these compounds in aqueous solutions [17, 18].

The Fig. 2 and Fig. 3 show the UV spectra in protic solvents for the investigated compounds I and III respectively, while for the compound II they are dropped out, because they are identical with the spectra of the compound I.

From the UV spectra presented in the Fig. 2 and Fig. 3 it could be noticed that one intensive band at higher wavelength (about $255 \mathrm{~nm}$ for the compound II and about $260 \mathrm{~nm}$ for the compound III) and another one, less intensive at lower wavelength (about $200 \mathrm{~nm}$ ) appear. The absorption bands which appear at higher wavelength were important for our further investigations. These bands probably anse as a result of $\pi \rightarrow \pi^{*}$ electron transitions in the 1,2,4-triazoline-3-thione ring [19]. 


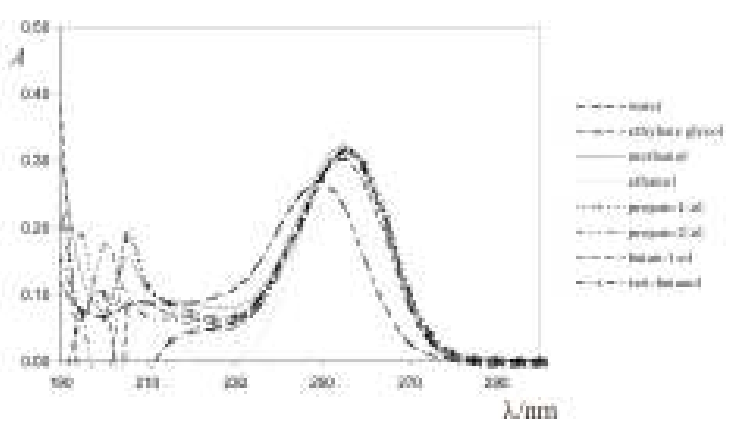

Fig. 2. UV spectra for 4-butyl-5-octyl-2,4-dihydro-3H-1,2,4triazoline-3-thione with concentration of $2.04 \cdot 10^{-5} \mathrm{~mol} / \mathrm{dm}^{3}$ in protic solvents

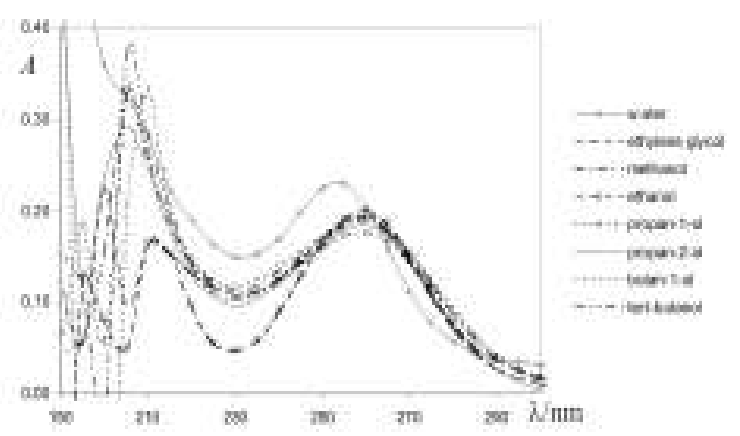

Fig. 3. UV spectra for 4-phenyl-5-octyl-2,4-dihydro-3H-1,2,4triazoline-3-thione with concentration of $2.03 \cdot 10^{-5} \mathrm{~mol} / \mathrm{dm}^{3}$ in protic solvents

The values of the wavelength which correspond to the absorption maxima $\left(\lambda_{\max }\right)$ were determined from the UV spectra of the investigated compounds I, II and III in protic solvents. The obtained results are given in Table 2.

From the Table 2 it could be noticed that for the investigated compounds I and II the absorption maxima of the spectra, recorded in protic solvents, appear at the wavelength region from $253 \mathrm{~nm}$ to $257 \mathrm{~nm}$. The exception is water, where the absorption maxima appear at about $250 \mathrm{~nm}$. On the other hand, for the compound III, the absorption maxima appear at higher wavelengths (from $254 \mathrm{~nm}$ in water to $262 \mathrm{~nm}$ in butan-1-ol) than those of the compounds I and II.

Furthermore, from the wavelength values, which correspond to the absorption maxima of the investigated compounds presented in Table 2, it could be seen that, the absorption maxima insignificantly shift bathochromic when the polarity of the solvent decreases.
The absorption maxima for the compound III were for 4-5 nm higher compared to that of the compounds I and II. The higher values of $\lambda_{\max }$ for the compound III were probably as a result of the influence of the phenyl group in the position 4 (compound I has butyl and compound II has alyl group), i.e. because of stronger conjugation of the electrons in the benzene ring. The same conclusion for similar compounds was performed by Nikolić et al. [20].

Table 2

The values of the absorption maxima wavelength $\left(\lambda_{\max }\right)$ for the compounds I, II and III in protic and aprotic solvents

\begin{tabular}{|c|c|c|c|}
\hline Solvent & $\lambda_{\max }^{\mathrm{I} / \mathrm{nm})^{*}}$ & $\begin{array}{c}\mathrm{II} \\
\left.\lambda_{\max } / \mathrm{nm}\right)\end{array}$ & $\begin{array}{c}\text { III } \\
\left(\lambda_{\max } / \mathrm{nm}\right)\end{array}$ \\
\hline \multicolumn{4}{|c|}{ Protic solvents } \\
\hline Water & 250 & 250 & 254 \\
\hline Ethylene glycol & 253 & 254 & 257 \\
\hline Methanol & 254 & 255 & 258 \\
\hline Ethanol & 255 & 255 & 259 \\
\hline Propan-1-ol & 256 & 256 & 258 \\
\hline Propan-2-ol & 254 & 256 & 259 \\
\hline Butan-1-ol & 255 & 257 & 262 \\
\hline tert-Butanol & 255 & 256 & 261 \\
\hline \multicolumn{4}{|c|}{ Aprotic solvents } \\
\hline Chloroform & 259 & 259 & 263 \\
\hline Acetonitrile & 258 & 259 & 263 \\
\hline Dioxane & 260 & 260 & 264 \\
\hline Dimethylsulfoxide & 264 & 264 & 266 \\
\hline$N, N$-Dimethylformamide & 264 & 264 & 266 \\
\hline
\end{tabular}

By considering the equilibrium between 3thione and 3-thiol tautomeric forms (Fig. 1, I-II) in solvent of different polarity, it has been found that the increasing solvent polarity the equilibrium shifts towards the thione form [21]. This form is more dipolar than the thiol form due to the contribution of the charge-separated mesomeric form (Fig. 1, I-a). Our results are in agreement with this explanation. Furthermore, the hydrogen bonding ability of the solvent plays an important role since 
hydrogen-bond donors tend to stabilize the thione form (Fig. 1, I), while hydrogen-bond acceptors stabilize the thiol form (Fig. 1, II).

As we mentioned before, to examine the influence of the solvent on the investigated compounds, the solvatochromic coefficients were calculated using the general solvation Eq. (1) [1315]. The absorbance frequencies $\left(\tilde{V}_{\max }=1 / \lambda_{\max }\right)$ were correlated with the total solvatochromic parameters $\alpha, \beta$ and $\pi^{*}$ for the solvents (Table 1 ) and the experimental obtained data for $\lambda_{\max }$ (Table 2). The values of $\tilde{V}_{\max }\left(\mathrm{nm}^{-1}\right)$ were multiplied with $10^{4}$ in order to obtain higher values that were easier to compare. The calculations were made using the computer programme Excel. The obtained results in polar protic solvents, the standard deviation $(S D)$, the correlation coefficients $(R)$ and the number of used solvents $(n)$ are presented with the following Eqs. (2-4):

For 4-butyl-5-octyl-2,4-dihydro-3H-1,2,4-triazoline-3-thione:

$$
\begin{gathered}
\tilde{V}_{\max }=38.10+1.08 \pi^{*}+0.49 \alpha+0.29 \beta \\
(R=0.921, S D=0.11, n=8)
\end{gathered}
$$

For 4-allyl-5-octyl-2,4-dihydro-3H-1,2,4-triazoline-3-thione:

$$
\begin{gathered}
\tilde{V}_{\max }=38.22+1.25 \pi^{*}+0.25 \alpha+0.051 \beta \\
(R=0.896, S D=0.14, n=8)
\end{gathered}
$$

And for 4-phenyl-5-octyl-2,4-dihydro-3H1,2,4-triazoline-3-thione:

$$
\begin{gathered}
\tilde{V}_{\max }=37.93+0.80 \pi^{*}+0.52 \alpha-0.29 \beta \\
(R=0.871, S D=0.17, n=8)
\end{gathered}
$$

The solvatochromic coefficient $s$, which expresses the influence of the polarity of a solvent (classic solvation effects, $\pi^{*}$ ), has a positive sign (Eqs. 2-4) for all investigated compounds. The positive sign of $s$ indicates a better stabilization of the ground state (see Fig. 1, I). The solvatochromic coeficient $s$ has higher value compared with the coefficients $a$ and $b$ for all investigated compounds. It showed that the polarity of the solvent i.e. the classic solvation effects $\left(\pi^{*}\right)$ dominate in stabilization of the ground state in protic solvents.
The solvatochromic coefficient $a$ expresses the influence of the solvent hydrogen-bond donor (HBD) acidity, while the solvatochromic coefficient $b$ expresses the influence of the solvent hydrogen-bond acceptor (HBA) basicity. The higher values of the solvatochromic coefficient $a$, compared to the coefficient $b$, for all investigated compounds suggest that the HBD solvent effects dominate in protic solvents.

The values of the solvatochromic coefficient $a$ have a positive sign for all investigated compounds. It means that the HBD effects of the solvent are in the same direction to the classic solvation effects $\left(\pi^{*}\right)$ and, however, contribute in stabilization of the ground state of the compounds (Fig. $1, \mathrm{I})$.

The solvatochromic coefficient $b$ has a negative sign (see Eq. 4) for the compound III. It means that the influence of the HBA effects ( $\beta$ parameter) of the solvent is in the opposite direction to the HBD effects and classic solvation effects $\left(\pi^{*}\right)$. The solvatochromic parameter $\beta$ favoured the transition state, but the value of solvatochromic coefficient $b$ is smaller compared to the solvatochromic parameters $a$ and $s$ suggesting that its influence is less important.

As we mentioned before, the investigated compound III in position 4 has a phenyl group, hence, this compound is more sensitive to the HBD effects of the solvents, comparing with the other investigated compounds, which in this position have the butyl group (compound I) and the allyl group (compound II). This is confirmed with higher values of the solvatochromic coefficient $a$ for the compound III compared with those of the compounds I and II (Eqs. 2-4). This behaviour of the compound III is in agreement with the acknowledgement that the $\pi$ electronic system of the aromatic compounds could probably represent the weak acceptor of protons (i.e. could form hydrogen bonds) [22].

Generally, the protic polar solvents stabilize the ground state of the compounds (positive values of the solvatochromic coefficient $s$ ). The role of polarity of the solvent for this purpose is also important. From the higher values of the coefficient $s$ it could be concluded that the investigated compounds are the most sensitive to the polarity of the polar protic solvents. It is probably so as a result of the more polarized structure of the compounds in the ground state and the decreasing hydrogen-bond 
accepting the solvent effect when more dipolar tautomeric form $\mathrm{HN}=\mathrm{C}-\mathrm{S}^{-}$transforms in the $\mathrm{N}=\mathrm{C}-$ SH tautomeric form (Fig. 1, I, I-a, II). The influence of the classic solvation effect is increased with the influence of the HBD and HBA effects (exception is the compound III where the HBA effects are in the opposite direction).

Simultaneously, the UV electronic spectra were recorded in polar aprotic solvents. The obtained UV spectra for the compound II are shown in Fig. 4 and the ultraviolet data for the absorption maxima of all investigated compounds are presented in Table 2. As it was the case in protic solvents, the UV spectra for compounds I and II are identical, while those for the compound III are shifted towards longer wavelengths about $4 \mathrm{~nm}$.

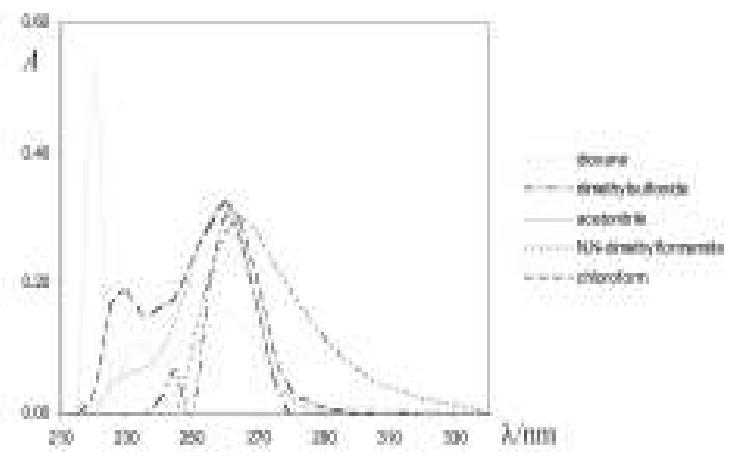

Fig. 4. UV spectra for 4-allyl-5-octyl-2,4-dihydro-3H-1,2,4triazoline-3-thione with concentration of $2.00 \cdot 10^{-5} \mathrm{~mol} / \mathrm{dm}^{3}$ in aprotic solvents

Examination of the data given in Table 2 (Fig. 4) indicated that the absorption maxima for the investigated compounds I, II and III in aprotic solvents appear at higher wavelengths than in protic solvents (see Table 2). Namely, the absorption maxima of the compounds I and II appear in the region from $258 \mathrm{~nm}$ to $264 \mathrm{~nm}$, while for the compound III they appear from $263 \mathrm{~nm}$ to $266 \mathrm{~nm}$.

Comparing the absorption maxima in protic and aprotic solvents it could be noticed that the absorption maxima shift bathochromic probably as a result of the interactions compound-solvent. It shows that the solvation effect of the aprotic solvent has greater influence on this kind of compounds, while higher values of the absorption maxima show that smaller energy is needed, for the electron transfer processes in aprotic solvents.
From the experimental UV spectroscopic data (Table 2) and the values of the solvatochromic parameters (Table 1), the solvatochromic coefficients $s, a$ and $b$ in aprotic solvents were calculated using the Eq. (1) [13-15]. Their values are given with the Eqs. (5-7):

For 4-butyl-5-octyl-2,4-dihydro-3H-1,2,4triazoline-3-thione:

$$
\begin{gathered}
\tilde{V}_{\max }=38.49+4.42 \pi^{*}-5.48 \alpha-6.80 \beta \\
(R=0.883, S D=0.28, n=5)
\end{gathered}
$$

For 4-allyl-5-octyl-2,4-dihydro-3H-1,2,4-triazoline-3-thione:

$$
\begin{gathered}
\tilde{V}_{\max }=38.72+2.50 \pi^{*}-3.48 \alpha-4.54 \beta \\
(R=0.905, S D=0.23, n=5)
\end{gathered}
$$

For 4-phenyl-5-octyl-2,4-dihydro-3H-1,2,4triazoline-3-thione:

$$
\begin{gathered}
\tilde{V}_{\max }=37.95+1.74 \pi^{*}-2.08 \alpha-2.83 \beta \\
(R=0.912, S D=0.13, n=5)
\end{gathered}
$$

The results obtained using the LSER method [13-15] for aprotic solvents (Eqs. 5-7) are different from those obtained for protic solvents (Eqs. 2-4). The analysis of the solvatochromic coefficients $s, a$ and $b$ for the compounds I, II and III (Eqs. 5-7) shows that the transition state is stabilized with the HBA effects in aprotic polar solvents (a negative sign of the coefficient $b$ ). This state is additionally stabilized with the influence of the HBD effects (a negative sign of the coefficient a). This result supported the existence of the compounds in the thione-thiol tautomeric equilibrium (see Fig. 1). The stabilization of the transition state for these compounds decreased as a result of the influence of the classic solvation effect ( $s$ has a positive sign).

The obtained values of the correlation coefficients $(R)$ for the investigated compounds show satisfactory correlation, i.e they are between 0.871 and 0.921 . The values of the percentage contribution of solvatochromic coefficients $s, a$ and $b$ are presented in Table 3.

The influence of the classic solvation effects, HBA and HBD effects of the protic and aprotic solvents was also confirmed with the values of the 
percentage contribution of solvatochromic coefficients (Table 3).

Table 3

Percentage contribution of the calculated
solvatochromic coefficients in protic
and aprotic solvents (\%)

\begin{tabular}{cccc|ccc}
\hline \hline \multirow{2}{*}{ Compound } & \multicolumn{2}{c|}{ Protic solvents } & \multicolumn{3}{|c}{ Aprotic solvents } \\
\cline { 2 - 7 } & $s$ & $a$ & $b$ & $s$ & $a$ & $b$ \\
\hline I & 57.75 & 26.63 & 15.61 & 26.45 & 32.83 & 40.71 \\
II & 80.84 & 15.86 & 3.292 & 23.69 & 33.15 & 43.14 \\
III & 49.58 & 32.03 & 18.38 & 26.15 & 31.31 & 42.54 \\
\hline \hline
\end{tabular}

\section{CONCLUSIONS}

The obtained results in protic solvents show that the polarity of the solvent dominates in stabilization of the ground state rather than other effects. While, in aprotic solvents the transition state is stabilized with the HBA and HBD effects. The values of the percentage contribution of solvatochromic coefficients additionally confirm this conclusion. Comparing the values of the solvatochromic coefficients $s, a$ and $b(2)-(7)$ for protic and aprotic solvents it could be concluded that the influence of the aprotic solvents is more significant than the influence of the protic solvents. So, the aprotic solvents are more convenient as a medium for examination of the reactions of the investigated compounds, because they favoured the transition state. The satisfactory correlation of the electronic absorption frequencies of the investigated 1,2,4triazoline-3-thiones with the Eq. (1) indicated that the correct model was selected. It demonstrated that a solvatochromic Eq. (1) with three solvatochromic parameters $\pi^{*}, \alpha$ and $\beta$ can be used to evaluate the effects of both types of hydrogenbonding and solvent polarity effect on the investigated thiones.

\section{REFERENCES}

[1] M. Tandon, J. P. Barthwal, T. N. Bhall, K. P. Bhargava, Synthesis and antiinflamatory activity of some new 3-(osubstituted phenyl)-4-substituted-phenyl-5-alkyl/alkenylmercapto-1H-1,2,4-triazoles, Indian J. Chem., 20B, 1017-1022 (1981).
[2] A. A. B. Hazzaa, I. M. Labouta, M. G. Kassem, Synthesis, Antibacterial and Antifungal Activity of 4-Substituted-5Aryl-1,2,4-Triazoles, Arch Pharm. Chem. Sci., 11 (2) 4357 (1983).

[3] B. N. Goswami, J. C. S. Kataky, J. N. Baruah, Synthesis and antibacterial activity of 1-(-2,4-Dichlorobenzoyl)-4substituted thiosemicarazides, 1,2,4-triazoles and their methyl derivatives, J. Heterocyclic Chem., 21, 1225 1229 (1984).

[4] A. R. Jalilian, S. Sattari, M. Bineshmarvasti, A. Shafiee, M. Daneshtalab, Synthesis and in vitro antifungal and cytotoxicity evaluation of thiazolo- $4 H-1,2,4$-triazoles and 1,2,3-thiadiazolo-4H-1,2,4-triazoles-1,2,4-4H-triazolesthiazoles-1,2,3-thiadiazoles, Arch. der Pharmazie, 333, 347-354 (2000).

[5] P. J. Kothari, M. A. Mehlhoff, S. P. Singh, S. S. Parmar, V. I. Stenberg, Synthesis of 5-(1-Naphthylmethyl)-4-aryls-triazol-3-thiolyl/ylthioglycolic acids as possible antiinflammatory agents, J. Heterocyclic Chem., 17, 13691372 (1980).

[6] N. Guelerman, S. Rollas, M. Uelgen, Synthesis and in vitro microsomal metabolism of 4-ethyl-5-(4-fluorophenyl)-2,4-dihydro-3H-1,2,4-triazole-3-thione and its potential metabolities, Boll. Chim. Farm., 137 (5), 140-143 (1998).

[7] K. C. Ragenoviḱ, V. Dimova, V. Kakurinov, D. M. Gabor, A. Buzarovska, Synthesis and antibacterial and antifungal activity of 4-substituted-5-aryl-1,2,4-triazole, Molecules, 6, 815-824 (2001).

[8] A. S. Galabov, B. S. Galabov, N. A. Neykova, Structureactivity relationship of diphenylthiourea antivirals, $J$. Med. Chem., 23, 1048-1061 (1980).

[9] S. Rollas, S. Büyüktimkin, A. Çevikbas, Platinum-mediated synthetic process for il4-1, 2,4-oxadiazolines, Arch. Pharm. (Weinheim), 324, 189-198 (1991).

[10] B. S. Holla, B. Kalluraya, K. R. Sridhar, Synthesis of 4(5-nitro-2-furfurylidene) amino-3-mercapto-5-(substitutedtriazoles as possible antibacterial agents, Curr. Sci., 56, 236-238 (1987).

[11] N. Kalyoncuğlu, S. Rollas, D. Sur-Altiner, Y. Yeğenğlu, O. Aug, 1-[p-(Benzoylamino) benzoyl]-4-substituted thiosemicarbazides: synthesis and antibacterial and antifungal activities, Pharmazie, 47, H. 4, 796-797 (1992).

[12] K. C. Ragenoviќ, V. Dimova, V. Kakurinov, D. M. Gabor, Synthesis of 1-Nonanoyl/octadecanoyl 1-4-substituted Thiosemicarbazides and substituted 1,2,4-Triazoles as biological active compounds, J. Heterocyclic Chem., 40, 905-908 (2003).

[13] M. J. Kamlet, R. W. Taft, The Solvatochromic Comparison Method. I. The $\beta$-Scale of Solvent Hydrogen-Bond Acceptor (HBA) Basicities ${ }^{1}$, J. Am. Chem. Soc., 98, $377-$ 383 (1976).

[14] M. J. Kamlet, R. W. Taft, The Solvatochromic Comparison Method. 2. The $\alpha$-Scale of Solvent Hydrogen-Bond donor (HBD) Acidities, J. Am. Chem. Soc., 98, 28862894 (1976).

[15] M. J. Kamlet, R. W. Taft, The solvatochromic comparison method. 6. The $\pi^{*}$ scale of solvent polarities, J. Am. Chem. Soc., 98, 6027-6038 (1976). 
[16] S. Rollas, N. Kalyancioğlu, D. Sür-Altıner, Y. Yeğenoğlu, 5(4-Aminophenyl)-4-substituted-2,4-dihydro-3H-1,2,4triazole-3-thiones: Synthesis and antibacterial and antifungal activities. Pharmazie, 48, 308-309 (1993).

[17] M. Jankulovska, I. Spirevska, K. Č. Ragenoviќ, Behaviour of some newly synthesized substituted 1,2,4-triazoline-3-thiones in sulfuric acid media, Bull. Chem. Technol. Macedonia, 25 (1) 29-37 (2006).

[18] M. Jankulovska, I. Spirevska, L. Šoptrajanova, Determination of the dissociation constants of some newly synthesized derivatives of 1,2,4-triazoline-3-thione in sodium hydroxide media, Bull. Chem. Technol. Macedonia, 25 (2), 99-106 (2006).
[19] A. Albert, E. P. Serjeant, The Determination of Ionization Constants, Chapman, London, 1971.

[20] J. B. Nikolić, G. S. Ušćumlić, V. V. Krstić, Solvent effect on electronic absorption spectra of cyclohex-1-enylcarboxylic and 2-methylcyclohex-1-enylcarboxylic acids, $J$. Serb. Chem. Soc., 65 (5-6) 353-359 (2000).

[21] C. Reichardt, Solvents and Solvent Effects in Organic Chemistry, Wiley-VCH, Weinheim, 2004, pp. 113-128.

[22] G. Desiraju, T. Steiner, Weak Hydrogen Bond in Structural Chemistry and Biology, Oxford University Press, Oxford/UK (1999) 117-129. 